\title{
Accountant's Perspective of Advances in Technology of Capital Assets and Financial Performance in Nigeria: A focus on the Construction Industry
}

\author{
Loveday A. Nwanyanwu ${ }^{1}$ \\ ${ }^{1}$ Department of Accountancy, Rivers State University of Science and Technology, Port Harcourt, Federal Republic of \\ Nigeria. \\ Correspondence: Loveday A. Nwanyanwu, Department of Accountancy, Rivers State University of Science and \\ Technology, Port Harcourt, Federal Republic of Nigeria.
}

Received: December 21, 2015

Accepted: January 6, 2016

Available online: January 20, 2016

doi:10.11114/aef.v3i1.1316

URL: http://dx.doi.org/10.11114/aef.v3i1.1316

\begin{abstract}
This paper examines from the accountant's perspective, the relationship between advances in technology of capital assets and financial performance of construction companies listed on the Nigerian Stock Exchange. Data were collected through questionnaire. Analyses were performed by means of descriptive statistics and Pearson product moment coefficient of correlation using the statistical package for social sciences (SPSS). Findings indicate that advances in technology of capital assets measured in terms of efficiency have a statistically significantly strong positive relationship with financial performance. Results of descriptive statistics indicate that efficiency of capital assets arising from advances in technology of capital assets influences contract patronages by $54.5 \%$. In conclusion, capital assets acquired without cognisance of global modernisation in machines and equipment may shortly suffer from obsolescence and thus become unable to deliver value for money services.
\end{abstract}

Keywords: Technology, Capital Assets, Financial Performance

\section{Introduction}

Technology is embracing and spreads across all facets of human endeavour. Its essence grows with complexities in service delivery. The efficiency of capital assets which constitute the hub of investment by organisations, particularly, construction companies, can only be achieved through advances in technology. The inability of some construction companies, especially, local contractors to respond to changes in technology have led to reduction in performance. According to Chiang, Tang and Leung (2001), local contractors belong to the group of builders with low technology in the private sector, competing intensively on cost reduction rather than technology improvement, leading to poor construction safety and product quality.

Scholars have in the past undertaken studies on technology. Ekpene (2006) focused on the acquisition of technological capabilities as a panacea for technological progress and industrialisation, noting that there can be no technological progress/industrialisation without the inculcation of technological culture into the attitude and mentality of Nigerians. In another development, N.E. Inyang, P.D. Inyang and Akinbobola (2006) investigated the implementation of technology education for national development in Akwa Ibom State, Nigeria based on a sample of 70 technical teachers. The study recommended the gearing of efforts towards provision of equipment and textbooks necessary for enhancing technology education programme.

These studies did not consider the impact of advances in technology of capital assets on organizational performance. It is the purpose of this study to empirically examine the influence of advances in technology of capital assets on financial performance of organisations, in an emerging economy, drawing evidence from construction companies which constitute key players in equipment consumption.

Next sections will discuss theoretical background, development of hypothesis and methodology. Others are data presentation and analysis, discussion of findings, conclusion and recommendations.

\section{Theoretical background}

\subsection{Technology}

Technology could be defined in various dimensions. It could be defined as a new idea, innovation or transformation of a thing into a unique tangible form. In the views of Hicks \& Gullet (1981: 380), a firm's technology is a reflection of the environment in which it operates. Technology includes the machines and tools used to produce a product or service. More broadly, it is defined as the process of transforming raw material into a desired output (Wieland \& Ullrich: 1976). This definition also covers the skills that an organisation's members use to produce the product or service. Technology can be viewed broadly or narrowly. When viewed broadly, technology can be regarded as a "cultural traditions" 
developed in a human community for meeting social needs. For instance, the arts involved in running, manufacturing, communication, etc. When viewed from a narrow perspective, technology is defined as the know - how or knowledge of how to do something, example, skills and procedures needed for performing a particular activity in the society (Stewart, 1977).

Construction companies are amongst organisations whose investments in equipment and machines are influenced by the level of innovation and technology. A field survey performed portrays majority of indigenous construction companies as not been able to invest in capital assets with improved technological application, thereby been unequipped to compete favourably in the industry. This fact accounts for the increase in patronage extended to multinational construction companies which embrace innovation and invest aggressively in equipment and machines with modern technology and performance.

Apart from Nigeria, construction companies in other countries that do not embrace innovation and investment in modern technologically driven equipment face severe competition and low demand for their services. The construction companies in Hong Kong, for instance, faced severe problems amongst which is lack of innovation, technology and applied research when the government in 2003 discontinued the sale and production of Home ownership scheme flats and terminated the private sector participation scheme (Chan, Tam \& Cheung 2005:114).The occurrence of innovation within the construction industry is often characterised by widespread adoption of new practices as a consequence of advances in technological and business processes (Lansley (1996).

The scope of possible technology based strategies for construction firms is broad. Recently, choices and means for technology development constitute the most interrogatory issue in technology strategy. According to Edum - Fotwe , Gibb and Benford-Miller (2004:366 - 377), the reports of Latham (1994) and Egan (1998) brought into light the differential rates of technology and managerial innovation in the delivery of construction infrastructure developments compared to other sectors, particularly, manufacturing. This was during the period $1990-2000$ when the UK government had the opportunity to modernise the construction industry following a recession; with the commitment to ensure that UK construction industry is able to compete with the best in the evolving climate of a globalised market for national economies (McCaffer \& Edum - Fotwe, 2000).

\subsection{Financial Performance}

Financial performance is the evaluation of a company by reference to its ability to satisfy corporate objective of earning profit. It constitutes an important area of assessment, taking into consideration expectations of investors. Financial ratios are commonly used measures for evaluating financial performance (R. Libby, P.A. Libby \& Short 2001: 740-741; Dyckman, Dukes \& Davies 1998: 190, Pandey 1979: 518-525 and Hicks \& Gullett 1981: 548). Data used to compute financial ratios are accounting related. They are objective and have the advantage of been compared to industry norms and to historical performance (Fry, Stones and Hattwick (1998:481). Some frequently used tests of financial performance are return on equity, return on asset, earnings per share, net profit margin, non-current asset turnover, price earnings ratio, dividend payout ratio, operating expenses ratio, return on capital employed, earnings yield; etc (Nwanyanwu, 2013:453 and Nwanyanwu, 2014:201). This study measures financial performance in terms of return on asset (ROA).

\subsection{Return on Asset}

Return on asset (ROA) is a profitability ratio used to evaluate efficiency in utilisation of investment in assets. According to Pandey (1979), it is a useful measure of the profitability of all financial resources invested in the firm's assets. The formular for calculating ROA is:

$$
\text { Net profit after tax }+ \text { Interest }
$$

$$
\text { ROA }=
$$

\section{Total Assets}

In real terms, the ROA identifies how much profit after tax is earned by investment in total assets. As stated by Libby $e t$ al (2001), majority of financial analysts consider the ROA to be a better measure of management's ability to effectively utilise assets independent of how they were financed. Also, the ROA according to Ainsworth, Deines, Plumlee and Larson (1997) is important because it includes the two fundamental profitability elements - earnings and investment in assets. The investment in assets element represents the total investment of the business and the ratio of net income to those assets measures the effectiveness of management in utilizing the resources at its command. In the view of Van Horne (2002), ROA represents the earning power of a company and permits comparisons to be made amongst organisations in the same industry as well as trend analysis of the performances of a company periodically.

Investment in equipment and machines constitute a major proportion of total investments in assets by an organisation. ROA is, therefore, considered important in evaluating the earning power of construction companies which are amongst 
industries that benefit extensively from the services of technologically driven capital assets (equipment, machines etc).

\section{Development of Hypothesis}

In the view of Soludo (1990), the essentiality of technology is its applicability to practical purposes. It provides a survival mechanism for every society and serves as a tool for meeting societal needs. Recent advances in technological innovations have led to increase in the performance of construction equipment. Therefore, organisations investing in capital assets are expected to take cognisance of innovations and advances in technology to satisfy the requirements of consumers in services delivery.

Studies have shown that organizations that were behind technological advances faced reduction in patronage. Chan et al (2005: 114) reported that the construction industry of Hong Kong faced drastic demand cut and encountered severe problems among which is lack of innovation, technology and applied research when the Government in 2003 stopped the sale and production of Home ownership scheme flats and terminated the private sector participation scheme. Chiang et al (2001: 675-87) pointed out that building contractors in Hong Kong thus compete intensively on cost reduction rather than technology improvement, leading to poor construction safety and product quality.

As stated by Lansley (1996), the occurrence of innovation within the construction industry is often characterised by widespread adoption of new practices as a result of advances in technological and business processes. The reason for such innovation as reported by Edum-Fortwe et al (2004:367) is that without it, organisations become engulfed by obsolescence. From the foregoing, the following hypothesis is formulated as a guide:

There is no significant relationship between efficiency of capital

asset arising from advances in technology with financial

performance measured in terms of return on asset.

\section{Methodology}

This study adopted a survey design. The objective is to obtain responses from the participants in the construction industry as to the relevance of advances in technology vis-a-vis the efficiency of capital assets (equipment) which from the accountant's definition of non - current assets, are used in generating income to achieve corporate objective of earning profit. Consequently, data were collected by means of questionnaire on a five point scale. This approach avoids possible managerial manipulations associated with historical financial statements. It also eliminates the heterogeneity of financial statements arising from differences in accounting policies.

Moreso, the essentiality of technology in the construction industry can better be understood from the responses of the operators than from historical financial statements. The works of Chan et al (2005: 115) used data from annual reports of eight representative large contractors listed in Hong Kong Stock Exchange to evaluate the performance of construction firms. While those of Cheah and Garvin (2004: 117) was an integration of both historical data and interviews. This present work is a departure as it concentrates on primary data to assess the influence of advances in technology of capital assets on the financial performance of construction companies in Nigeria, an emerging economy.

Advances in technology are measured in terms of efficiency (ECA) while financial performance is measured in terms of return on asset (ROA). The explanatory variable (ECA) has three questions while the criterion variable (ROA) also has three questions. Respondents were requested to indicate the extent to which advances in technology affect the efficiency of capital assets, ranging from "no extent" to "very great extent". On the same scale, they are to indicate the extent of replacement of capital assets following innovations in construction machines. This notwithstanding, on a five point scale ranging from "strongly disagree" to "strongly agree", respondents were required to state if contract patronages are a function of efficiency of capital assets. They are also to rate the ROA of their organisations from "fair" to "outstanding" and also their turnover in naira performance on the same scale. In order to obtain insight into the cumulative activities of the companies, respondents were required to comment on their overall financial performances from "low" to "high". Whereas these sub variables permit evaluation of the relevance of advances in technology to financial performance, the key variables for assessments are efficiency of capital asset (ECA) and return on asset (ROA).

The population consists of nine (9) construction companies listed on the Nigerian Stock Exchange. Construction business, because of huge capital commitment involved, does not attract many entrants (Nwanyanwu, 2015:83). This factor accounts for the few number of companies forming the population size. All the companies were studied, producing $100 \%$ sample size. Data were analysed using descriptive statistics and Pearson's product moment coefficient of correlation. The descriptive statistics provided information on mean scores and standard deviation while Pearson product moment coefficient of correlation facilitated the identification of the strength of relationship between the explanatory and criterion variables. 


\section{Data Presentation and Analysis}

Seventy two sets of questionnaire were distributed to the companies. Sixty were returned and after sorting and examination, fifty five representing a response rate of approximately $76.39 \%$ were used for analysis.

\subsection{Univariate Analysis}

\subsubsection{Frequency of Responses}

The frequency of responses from the respondents is shown in Table 1. Twenty respondents confirm that their companies replace capital assets moderately while fourteen representing $25.5 \%$ are of the opinion that their organisations to a great extent replace capital assets to accommodate changes in technology. On the other hand, seven respondents assert that their companies replace capital assets to a very great extent while twelve respondents maintain that capital assets are replaced to some extent. Average replacement of capital assets on a five point scale is 3 . A combination of responses on the $4^{\text {th }}$ and $5^{\text {th }}$ scales with the $3^{\text {rd }}$ scale indicate acceptance of capital asset replacement to accommodate advances in technology by $78.2 \%$ (43 respondents). Similarly, attribution of advances in technology to efficiency of capital assets is rated to a great extent from the views of twenty six respondents (47.3\%). In the opinion of fourteen respondents, efficiency of capital assets becomes eminent as a result of technological innovation to a very great extent. Whereas a total of fifteen respondents assert that it could be to some extent (3) or moderate (12), forty which is $72.8 \%$ attribute efficiency of capital assets to technological innovation. In another dimension, agreements as to whether contract patronages are influenced by efficiency of capital assets were: undecided 10, agree 23 and strongly agree 7 . Others are, strongly disagree 6 and disagree 9. Despite the views of a total of 25 respondents, the other 30 which is $54.5 \%$ collectively associate contract patronages to capital asset efficiency.

The association of efficiency of capital assets arising from advances in technology with financial performance as it affects sales turnover are good 9, very good 20, excellent 20 and outstanding 6 . The opinions expressed by the entire 55 respondents truly reflect the essentiality of technology on the efficiency of capital assets used in construction activities. With improved efficiency of capital assets, the impact on return on assets is good 15, very good 15 and excellent 25 . Overall financial performance ratings taking into consideration, the essence of technology are below average 2, average 32 , above average 19 and high 2 . Responses on the variables used to evaluate financial performance indicate that efficiency of capital assets arising from advances in technology improves profitability of organisations, particularly construction companies.

Table 1. Frequency of Responses.

\begin{tabular}{|c|c|c|c|c|}
\hline & Scale & Frequency & $\begin{array}{c}\text { Valid } \\
\%\end{array}$ & $\underset{\%}{\text { Cumulative }}$ \\
\hline Capital asset & 2 & 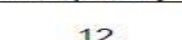 & & \\
\hline \multirow{4}{*}{$\begin{array}{l}\text { replacement } \\
\text { (CR) }\end{array}$} & 3 & 22 & 400 & $\begin{array}{l}21.8 \\
618\end{array}$ \\
\hline & 4 & 14 & 25.5 & 87.3 \\
\hline & & 7 & 12.7 & 100.0 \\
\hline & Total & 55 & 100.0 & \\
\hline \multirow{6}{*}{$\begin{array}{l}\text { Efficiency of } \\
\text { capital assets } \\
\text { (ECA) }\end{array}$} & & & & \\
\hline & 2 & 3 & 5.5 & \\
\hline & 3 & 12 & 21.8 & 27.3 \\
\hline & 4 & 26 & 47.3 & 74.5 \\
\hline & 5 & 14 & 25.5 & 100.0 \\
\hline & Total & 55 & 100.0 & \\
\hline \multicolumn{5}{|l|}{$\begin{array}{l}\text { Contracts based } \\
\text { on capital asset }\end{array}$} \\
\hline $\begin{array}{l}\text { on capital asset } \\
\text { efficiency }\end{array}$ & 1 & 6 & 10.9 & 10.9 \\
\hline \multirow{5}{*}{$\begin{array}{l}\text { efficency } \\
\text { (CCE) }\end{array}$} & & & & \\
\hline & $\frac{2}{3}$ & 10 & $\begin{array}{l}16.4 \\
18.2\end{array}$ & 45.5 \\
\hline & 4 & 23 & 41.8 & 87.3 \\
\hline & & 7 & 127 & 100.0 \\
\hline & 10 tal & & 100.0 & \\
\hline \multirow{6}{*}{$\begin{array}{l}\text { Turnover performance } \\
\text { (TP) }\end{array}$} & & & & \\
\hline & 2 & 9 & 16.4 & 16.4 \\
\hline & 3 & 20 & 36.4 & 52.7 \\
\hline & 4 & 20 & 36.4 & 89.1 \\
\hline & 5 & 6 & 10.9 & 100.0 \\
\hline & Total & & 100.0 & \\
\hline \multirow{3}{*}{$\begin{array}{l}\text { Return on Asset } \\
\text { (ROA) }\end{array}$} & 2 & 15 & 27.3 & 27.3 \\
\hline & 3 & 15 & 27.3 & 54.5 \\
\hline & $\stackrel{4}{\text { Total }}$ & $\begin{array}{l}25 \\
55\end{array}$ & $\begin{array}{l}45.5 \\
100.0\end{array}$ & 100.0 \\
\hline \multirow{5}{*}{$\begin{array}{l}\text { Overall Financial performance } \\
\text { (OFP) }\end{array}$} & & & & \\
\hline & 2 & 2 & 3.6 & 3.6 \\
\hline & & $\begin{array}{l}32 \\
19\end{array}$ & $\begin{array}{l}58.2 \\
34.5\end{array}$ & $\begin{array}{l}61.8 \\
96.4\end{array}$ \\
\hline & 5 & 2 & 3.6 & 100.0 \\
\hline & & & & \\
\hline
\end{tabular}

Frequency of responses from the respondents

Source: Survey data July 2015. Scale: CR and ECA = No extent 1 , some extent 2 , moderate 3 , great extent 4 , very great extent 5, CCE= strongly disagree (SDA) 1, disagree (DA) 2, undecided (UND) 3, agree (A) 4, strongly agree (SA) 5, ROA and TP = fair 1 , good 2 , very good 3 , excellent 4 , outstanding 5 . OFP = low 1 , below average 2 , average 3 , above 
average 4 , high 5 .

\subsubsection{Descriptive Statistics}

Table 2 presents the descriptive statistics on the variables examined. Replacement of capital assets in response to changes in technology is 3.2909 or approximately $65.82 \%$ on a 5 point scale. Efficiency of capital assets as a result of technology has a mean score of 3.9273 or approximately $78.55 \%$ also on a 5 point scale. This result reflects acceptance of innovations by construction contractors in other to satisfy consumers' requirements and improve financial performance. The mean score for contract patronages based on capital asset efficiency is 3.2909 or $65.82 \%$. Other factors account for contract patronages only to the extent of $34.18 \%$. Performance of capital assets is, therefore, vital for continuity in construction business.

Financial performance measures have mean scores of 3.4182 or $68.36 \%$ for turnover, 3.1818 or $63.64 \%$ for return on assets and 3.3818 or $67.64 \%$ for responses on aggregate (overall) financial performance. Profitability assessments arising from efficiency of capital assets are all above average. This is true when associated with the companies sampled as most of them are multinationals which embrace technology and innovations in construction activities.

Table 2. Descriptive Statistics

\begin{tabular}{lcc}
\hline & Mean & $\begin{array}{c}\text { Standard } \\
\text { Deviation }\end{array}$ \\
\hline $\begin{array}{l}\text { Capital asset replacement } \\
\begin{array}{l}\text { Efficiency of } \\
\text { capital assets }\end{array}\end{array}$ & 3.2909 & 0.95593 \\
$\begin{array}{l}\text { Contracts based on } \\
\text { capital asset efficiency }\end{array}$ & 3.9273 & 0.83565 \\
Turnover (स) performance & 3.2909 & 1.21217 \\
Return on assets performance & 3.4182 & 0.89631 \\
Overall financial performance & 3.1818 & 0.84087 \\
\hline
\end{tabular}

Descriptive statistics of variables studied.

Source: Survey data July, 2015. Scale: see Table 1

\subsection{Bivariate Analysis}

The strength of relationship between efficiency of capital assets (ECA) and return on assets (ROA) is shown in Table 3.

Table 3. Correlation analysis between efficiency of capital assets and return on assets

\begin{tabular}{|c|c|c|c|}
\hline & & $\begin{array}{l}\text { Technological } \\
\text { efficiency of } \\
\text { capital asset }\end{array}$ & $\begin{array}{l}\text { Return } \\
\text { on } \\
\text { asset }\end{array}$ \\
\hline $\begin{array}{l}\text { Technological } \\
\text { efficiency of } \\
\text { capital asset }\end{array}$ & $\begin{array}{l}\text { Pearson correlation } \\
\text { Sig. }(2-\text { tailed }) \\
N\end{array}$ & $\begin{array}{l}1 \\
55\end{array}$ & $\begin{array}{l}0.573^{\star \star} \\
0.000 \\
55\end{array}$ \\
\hline Return on asset & $\begin{array}{l}\text { Pearson correlation } \\
\text { Sig. }(2-\text { tailed }) \\
N\end{array}$ & $\begin{array}{l}0.573^{* *} \\
0.000 \\
55\end{array}$ & $\begin{array}{c}1 \\
55\end{array}$ \\
\hline
\end{tabular}

Correlation analysis showing strength of relationship between capital assets and return on assets

** Correlation is significant at the 0.01 level ( 2 - tailed)

The coefficient of correlation is 0.573 . This indicates a strong positive relationship between efficiency of capital assets (ECA) due to advances in technology and return on assets (ROA). The significance level is 0.01 (2-tailed) producing a level of confidence of $99 \%$. In otherwards, the likelihood that the analysis is correct is $99 \%$. Results, therefore, reject the hypothesis that there is no significant relationship between efficiency of capital assets arising from advances in technology and return on assets of construction companies.

The coefficient of determination is 0.3283 or $32.83 \%$. Efficiency of capital assets following advances in technology explains changes in return on assets by $32.83 \%$. Other factors aside technology of capital assets account for changes in return on assets by $67.17 \%$. 


\section{Discussion of Findings}

Results of univariate analysis indicate $78.2 \%$ acceptance of the need to replace capital assets to take cognisance of advances in technology. Similarly, $72.8 \%$ attribute efficiency of capital assets to innovations arising from technology. Also, efficiency of capital assets in recognition of advances in technology explains changes in contract patronages by $54.5 \%$. This notwithstanding, the influence of advances in technology of capital assets on return on assets (ROA) was rated $72.73 \%$ on aggregate (very good 15 and excellent 25). Findings confirm the essentiality of advances in technology and innovations in the construction industry. Contractors with low technology are unlikely to compete favourably with those that embrace technology. According to Chiang et al (2001: 114), local contractors belong to the group of builders of low technology in the private sector. They noted that, because of lack of technology, capital, job reference and expertise, this category of contractors cannot compete with international civil contractors from the UK, France, Germany, Australia and mainland China.

Bivariate analysis indicates a statistically significantly strong positive relationship between efficiency of capital assets as a function of advances in technology and return on assets. From this background, it has become paramount to recognise changes in technology in the management of construction business. For example, when the government of Hong Kong in 2003 stopped the sale and production of home ownership scheme flats and terminated the private sector participation scheme, the construction industry of Hong Kong faced drastic demand cut and encountered many severe problems, amongst which is lack of innovation, technology and applied research (Chan et al, 2005: 114). In fact, Raftery, Pasadilla, Chiang, Hui and Tang (1998: 729 - 37) suggested that, in the long run, technology acquisition through joint ventures with developed economies might leapfrog the gap in order to reduce the increasing inferiority of domestic contractors of low technology.

\section{Conclusion and Recommendations}

Advances in technology of capital assets measured in terms of efficiency has a statistically significantly strong positive relationship with financial performance measured in terms of return on assets; accounting for $32.83 \%$ of changes in return on assets. In addition, efficiency of capital assets arising from advances in technology influences contract patronages by $54.5 \%$. Other factors aside efficiency of capital assets contribute to contract patronages by $45.5 \%$. From the foregoing, capital assets acquired without cognisance of global modernisation in machines and equipment may shortly suffer from obsolescence and thus become unable to deliver value for money services.

This work is significant as it enriches literature on the influence of technology on financial performance in the context of quoted construction companies. Future studies may consider the influence of technology on unquoted construction companies. This is essential to evaluate their level of competition with multinational companies following globalisation of the construction industry.

\section{References}

Ainsworth, P., Deines D., Plumlee, R. D., \& Larson, C. X. (1997). Introduction to Accounting: An Integrated Approach; Boston, Irwin McGraw-Hill.

Chan, J. K. W., Tam, C. M., \& Cheung, R. K. C. (2005). "Construction Firms at the crossroads in Hong Kong, going insolvency or seeking opportunity", Engineering ,Construction and Architectural Management, 12(2),111-124. http://dx.doi.org/10.1108/0969998510584476.

Cheah, C. Y. J., \& Garvin, M. J. (2004). "An open framework for corporate strategy in construction” Engineering, Construction and Architectural Management, 11(3), 176-188. http://dx.doi.org/10.1108/09699980410535787.

Chiang, Y. H., Tang, B. S., \& Leung, W. Y. (2001). "Market Structure of the Construction Industry in Hong Kong”, Construction Management and Economics, 19, 675-87.

Dyckman, T. R., Dukes, R. E., \& Davis, C. J. (1998). Intermediate Accounting, Massachusetts, McGraw - Hill.

Edum-Fotwe, F. T., Gibb, A. G. F., \& Benford-Miller, M. (2004). "Reconciling construction innovation and standardisation on major projects" Engineering, Construction and Architectural Management, 11(5), 366-377, http://dx.doi.org/10.1108/09699980410558566.

Egan, J. (1998). "Re-thinking construction", Report of the construction Task Force on the scope for improving the quality and efficiency of UK construction, DETR, available at www.construction.detr.gov.uk/cis/rethink/index.htm.

Ekpene, L. (2006). "Developing Technological Capacity for National Self - Reliance in Nigeria", International Journal of Economics and Development Issues, 6(1), 94-102.

Fry, F. L., Stones, C. R., \& Hattwick, R. E. (1998). Business: An Integrated Framework, Boston, McGraw-Hill.

Hicks, H. G., \& Gullett, C. R. (1981). Management, New York, McGraw-Hill. http:// www.nse.com.ng/listings - 
site/listed - securities/

Inyang, N. E., Inyang, P. D., \& Akinbobola, A. O. (2006) "Implementation of Technology Education for National Development in Akwa Ibom State", Journal of Science and Technology Research, 5(1), 33-39.

Lansley, P. (1996). "Innovation; the role of research, education and practice". In Harlow, P. (Ed.), Construction papers, 59, CIOB, Ascot.

Latham, M. (1994). "Constructing the team", Joint Review of procurement and contractual arrangements in the United Kingdom construction industry: Final Report, HMSQ, London.

Libby, R., Libby, P. A., \& Short, D. G. (2001). Financial Accounting, New York, McGraw-Hill Companies Inc.

McCaffer, R., \& Edum-Fotwe, F. T. (2008) "Engineering and the future of the construction industry: realities and emerging possibilities" proceedings, $4^{\text {th }}$. Asia Pacific Structural Engineering and construction conference (ARSEC 2000). Kuala Lumpur, 13-16 September, 31-40.

Nwanyanwu, L. A. (2013). "Hire purchase strategy of physical capital investment and financial performance of construction companies: illustrating from the Nigerian Stock Exchange", Mediterranean Journal of social Sciences, $4(4), 453$.

Nwanyanwu, L. A. (2014). "Cost of loan capital and capital asset acquisition in Nigeria: implications on organisational profitability”, European Journal of Business and Management, 6(26), 201.

Nwanyanwu, L. A. (2015). “Outright cash purchase of capital assets and enterprise profitability in Nigeria: A reflection on the construction industry", Applied Finance and Accounting, 1(2), 81- 87.

Pandey, I. M. (1979). Financial Management, New Delhi, Vikas Publishing House PVT Ltd.

Raftery, J., Pasadilla, B., Chiang, Y. H., Hui, E. C. M., \& Tang, B. (1998) "Globalisation and construction industry development: implications of recent developments in the construction sector in Asia", Construction Management and Economics, 16(6), 729-37.

Soludo, C. C. (1990). "Technology in Economic Development of the Developing Economies: some theoretical and policy issues", Proceedings of Nigerian Economic Society Annual conference on capital goods and Technological Development in Nigeria, Ibadan, NES.

Stewart, F. (1977). Technology and Underdevelopment, London, Macmillan publishers.

Van Horne, J. C. (2002). Financial Management and Policy, Delhi, Pearson Education Inc.

Wieland, G. F., \& Ullrich, R. A. (1976). Organisations: Behavior, Design and Change, Homewood, Irwin.

\section{(cc) BY}

This work is licensed under a Creative Commons Attribution 3.0 License. 